\title{
The role of innovative entrepreneurship in the economic development of EU member countries
}

\author{
Rodica Crudu ${ }^{1}$
}

\begin{abstract}
In the specialized literature, entrepreneurship has been acknowledged to have a salient role in driving innovation, economic growth, and welfare, in addition to its effect on job creation. Researchers have expressed different views about the relationship between economic development and entrepreneurship throughout time. It is also considered that innovation is a driving force in the economic development of nations. Therefore, innovative entrepreneurship started to be considered a key factor in modern economic development. For instance, SMEs and innovation lay at the core of the European Union's development strategy - Europe 2020 strategy. The aim of the article is to analyze the role of innovative entrepreneurship in the economic development of EU member states. Taking into consideration that both processes: economic development and innovative entrepreneurship are multifaceted, the article comes to express the relationship between the two phenomena and its specifics in EU member countries. Given the nature of contemporary highlights of the literature review and the stated research objective, in this article, a model was tested that captures the new or young and innovative firms, as aspects of innovative entrepreneurship and determinants of the economic growth rates. The research method used is regression model analysis. For the statistical data analysis and processing, Stata and SPSS software tools were used. The key findings of the paper show that innovative entrepreneurs (being measured by the Total Early-stage Entrepreneurial Activity (TEA) innovation level) are more present in countries with higher development levels and higher incomes, being motivated by the improvement opportunity they see in becoming entrepreneurs. However, a higher degree of entrepreneurship, especially new firms' creation, does not substantially contribute to accelerated economic development. This is explained by the variation in the motivation (necessity or improvement oriented) entrepreneurs across EU countries.
\end{abstract}

1 Rodica Crudu, Ph.D., Associate Professor, Dean of the Faculty of International Economic Relations, Academy of Economic Studies of Moldova, 61 Banulescu-Bodoni str., MD-2005, Chișinău, Republic of Moldova, e-mail: rodikakrudu@gmail.com (ORCID ID 0000-0002-6470-8601).

Received 18 July 2018; Revised 28 November 2018, 3 December 2018, 11 January 2019, 13 February 2019; Accepted 15 February 2019 
In the developed countries, the entrepreneurs are most likely to be the Schumpeterian type, while in developing countries most of them are shopkeepers. Consequently, it is clear that EU member countries need friendlier and more efficient new firms' creation policies, as well as SME supporting tools. The paper has significant practical implications for decision and policy-making authorities in terms of possible directions for innovative entrepreneurship policy development.

Keywords: innovation, entrepreneurship, new firms' creation, European Union, economic growth.

\section{INTRODUCTION}

In the last decades, especially after the 2008 global crisis, entrepreneurship and innovation have become one of the main concepts in the business fields and public development policies. Its relevance has increased, as entrepreneurship is more often associated with the ability to create new products or services, to innovate. There is a large growing body of research that shows that there is an interrelation between entrepreneurship, innovation and economic development. Researchers have expressed different views about the relationship between entrepreneurship and economic development during this time. However, in the latest period, more and more importance has started to be assigned to the role of innovative entrepreneurs in economic development enhancement. Innovative entrepreneurs are considered to be those entrepreneurs that manage to transform innovative ideas into highdemand, marketable products, services or technologies and, therefore, innovations play a specific role for them as an instrument in earning innovative incomes. Innovative entrepreneurship has sparked increased interest among academia and politics as well. For instance, SMEs and innovation lay at the core of the European Union's development strategy - Europe 2020 strategy.

Despite its relevance, in the specialized literature, there is little empirical evidence on the contribution of those entrepreneurs that are considered to be innovative to the economic development of EU member countries. There are several studies, both theoretical (e.g., Holmes \& Schmitz, 1990; Shane, 2003; Acs, Audretsch, \& Lehmann, 2013) and empirical (e.g., Evans \& Leighton, 1989), determining the drivers of entrepreneurship development and the contribution of entrepreneurial activity to economic performance. However, the gap is determined by the constraints in the theoretical framework of innovative entrepreneur approach and the measurement of its impact at the national level. Most of the studies assess the economic performance at the level of the firm (Audretsch, 1995; Caves, 1998; Sutton, 1997) and show a positive relation between entrepreneurial activity and growth (i.e., new innovative firms become larger than existing large ones). 
Another fact that emerged from the existing literature analysis is that the relationship between entrepreneurial activity and economic development covers mostly geographic regions. Few studies tie the link of entrepreneurship in different regions to their economic performance (e.g., Audretsch \& Fritsch, 2002; Acs \& Armington, 2003) and only the Global Entrepreneurship Monitor (GERA, 2017) is linking entrepreneurship to economic performance at the national level. However, despite numerous research studies that endorse the relationship between entrepreneurship and economic growth, there is a relative hole in the literature regarding the assessment of the contribution and role of innovative entrepreneurship in the economic development of EU member countries.

The present paper has the objective to research the role of innovative entrepreneurship in the economic growth of EU member states. Taking into consideration that both processes: economic growth and innovative entrepreneurship are multifaceted, this paper analyzes the relationship between the two phenomena and its specifics in EU member countries, which are heterogeneous too. Consideration is also given to the fact that there is a reversed causality, in that the quality of entrepreneurial activity is influenced by the level of economic development.

The second section of this paper presents the literature literature on the relation and effects of entrepreneurship on economic development. Firstly are analyzed the studies that measure the effect of entrepreneurs on economic growth through job creation and the transformation of ideas into marketable products and welfare. Afterward, new trends in assessing the role of innovative entrepreneurs and their contribution to the economic growth acceleration are described. In the third section, the hypothesis to be tested are formulated, the data used in the hypothesis' testing are described and the model for regression analysis is designed. The analysis of the model and the findings are presented in the fourth section, and conclusions and final remarks are presented in the fifth section.

\section{LITERATURE REVIEW}

In the last decades, entrepreneurship has sparked salient interest and is considered an important driver of economic development, inclusive society, welfare, and as a source of innovation creation. In the economic literature, there are two trends in assessing the effects of entrepreneurship on economic development. One is based on horizontal innovation growth models and an increasing range of product (e.g., Romer, 1990). The other one relies on vertical innovation growth models and increasing quality (e.g., 
Schumpeter 1934, 1942; Aghion \& Howitt, 1992), being mostly explained by Joseph Schumpeter's famous "creative destruction" argument, according to which, when an entrepreneur introduces on the market a new product or a technological innovation, it pulls out from the market the less productive firms, and, therefore, creates a more competitive environment that leads to higher productivity and economic growth (Schumpeter, 1934). Since then, Acs, Braunerhjelm, Audretsch and Carlsson (2009) and Pontus et al., (2010) have completed the economic literature with the knowledge spillover theory of entrepreneurship. The authors induce the idea that economically relevant knowledge is the one that matters the most, with entrepreneurship playing the role of nexus between the knowledge and commercialization and economic growth.

The influence of innovation on economic growth is largely addressed in the economic literature. In the scholars' debates, the existent approaches, i.e., the evolutionary approach and the neoclassical "endogenous growth theory," are argued as having rooted differences. The evolutionary approach takes into consideration the historical environment, the causality between events and mechanisms, and treats economic growth as being far from a constant equilibrium. Whilst the neoclassical theory approaches economic growth as a state phenomenon, the cause and effects were analyzed as separate aspects (Fagerberg, Mowery, \& Nelson, 2009)

When assessing the role of innovation in economic growth, researchers more often use input (i.e., R\&D expenditures) or output (i.e., patents) measures (Griliches, 1990) and try to analyze the technological innovation's contribution, specifically at the firm and industry level. They are primarily based on a neo-classical approach established by Solow (1956) and use a Cobb-Douglas production function to establish the impact of the innovation on economic growth. It is worth mentioning that the studies that use neoclassical models of economic growth do not approach the entrepreneurship issue, which is the main trigger of technological innovation.

Recent scholarly debates try to endogenize the contribution of innovation to economic performance, referring to several forms of innovation: pedagogical innovation, active learning and learning by doing (Romer, 1986); human capital (Lucas, 1988); R\&D in innovative goods, services or processes (Romer, 1990; Aghion \& Howitt, 1992); and public infrastructure (Barro, 1990). The new growth theories seek to try out whether the elasticity of the output, with respect to broad capital (measured in one of the four forms revealed above), is higher than its share in value added or gross-output (Cameron, 1996). The endogenous growth models acknowledge the role of entrepreneurship in economic growth, by explaining the invention process and the main reasons that motivate firms to innovate (Uppenberg, 2009). 
Many studies that focused on assessing the impact of entrepreneurship on economic development rely on the contribution of entrepreneurship to job creation. Entrepreneurship, measured by the self-employment rate, is seen to positively and robustly influence annual GDP growth (Pontus et al., 2010). Additionally, new firms' creation is found to have a positive impact on employment growth (Folster, 2000; Acs \& Armington, 2004). Despite the theoretical arguments supporting the positive role of entrepreneurship in economic development, the heretofore unequivocally positive impacts of small and medium enterprises (SMEs) on job creation, have been recently thrown in relative uncertainty. Not all researchers have found positive correlations between entrepreneurship and job gains, with small firms having a disproportional contribution to net job creation (Birch, 1987; Shane, 2005; Henrekson \& Johansson, 2010; Neumark, Wall, \& Zhang 2011; Naudé, 2011; Haltiwanger, Jarmin \& Miranda 2013). Some researchers also suggest that entrepreneurship has a negative impact on economic growth. Using econometric and statistical techniques, it has been found that entrepreneurship, measured by the self-employment rate, in more than half of the OECD countries analyzed, had a negative impact on real GDP growth in the period 1966-1996 (Blanchflower, 2000) and on GDP per capita in the period 1980-1995 (Salgado-Banda, 2007). Carree van Stel, Thurik and Wennekers' (2007) findings display a non-linear effect, suggesting that the effect of entrepreneurship on economic growth is insignificant.

In addition to its effect on job creation, entrepreneurship is seen as a fertile environment for innovation creation and, therefore, has been acknowledged as a key mechanism for economic growth acceleration and welfare (Wennekers \& Thurik, 1999; Audretsch \& Thurik, 2001; Audretsch, Bönte, \& Keilbach, 2008; van Praag \& Versloot, 2007; Acs, Astebro, Audretsch, \& Robinson, 2016). However, according to Scott Shane (2009), the winner of the 2009 Global Award for Entrepreneurship Research, not all firms contribute to job creation and economic growth. He finds an interrelation between the motivation of becoming an entrepreneur and its effect on job generation and innovation creation. In those cases where self-employment is driven by necessity (the lack of a job or salary), these entrepreneurs are not likely to create job places, are likely to generate low incomes and are less likely to innovate. Hence, the author contends that mostly young firms, rather than small ones, contribute to job creation and contribute the most to economic growth and welfare acceleration (Shane, 2009). Business owners are not necessarily innovative and innovative entrepreneurs represent only a small fraction of them. This idea is also supported by \& van der Velde (2014) that suggests that industries dominated by small and young firms are more innovative than industries dominated by large firms. Furthermore, some 
studies demonstrate that, when employing analysis oriented to measure the impact of entrepreneurship on economic growth using data about firms that assimilate innovations (Levine \& Rubinstein, 2013), innovative and high growth entrepreneurs (Shane, 2009) or firms that use venture capital for their development (e.g., Lerner 1994), the results of the measurements show positive correlations.

Therefore, innovation comes to be treated as the "golden ingredient" of entrepreneurship in the quest for increased competitiveness and represents the main function of the highest-level entrepreneurs, who generate bright ideas and convert these ideas into marketable products which, consequently, are the most likely to create growth. The concept of innovative entrepreneurship has started to be used by researchers more often while trying to establish the effects of entrepreneurship, innovation and economic development. Some researchers call the innovative entrepreneurs "Schumpeterian entrepreneurs" (Block, Fisch, \& van Praag, 2017; Szabo \& Herman, 2012) as they are inspired by Schumpeter, one of the most influential economists of the twentieth century, his Theory of Economic Development (1911), and his conceptualization of "entrepreneur as innovator" - a key to accelerating economic development.

However, van Praag and Versloot (2007) allege that there is a dearth of evidence of differences between those young innovative firms that do create the aforementioned benefits for society and the economy, and their counterparts. A review of the economic literature helped us to systematize the main differences between traditional and innovative entrepreneurs. These differences rely on 1) Different sources of opportunities. In his book, A General Theory of Entrepreneurship, Scott Shane mentions that innovative entrepreneurship originates from a nexus of individuals and opportunities (Shane, 2003), and, in the case of the innovative entrepreneur, these opportunities are research-driven and knowledge/technology-based (Acs et al., 2009); 2) Academic education and technological background (Koellinger, 2008). Blanchflower (2000) suggests that the relationship between education and self-employed individuals features a U-shaped curve, meaning that the least and most educated have the highest percentage of self-employed individuals. His study is realized on a sample of 19 OECD countries and the findings prove to be robust across data sources, time periods and sample countries; 3) The ecosystem in which they operate, i.e., the existence of networks, clusters that would facilitate technology and knowledge transfer, availability of a skilled labor force, financial resources, supporting institutions, etc. (Kressel \& Lento, 2012).

Despite the theoretical arguments supporting the positive role of innovative entrepreneurship in fostering economic growth, the empirical 
evidence regarding its effects on economic growth is mixed. Even if there are studies that found a positive correlation between innovative entrepreneurship and economic growth, a complex causal relationship between them is not sufficiently acknowledged. Indeed, establishing the effects of entrepreneurship on economic development and innovation creation is technically challenging. In reality, entrepreneurship may not only affect innovation, but innovation may, in turn, affect entrepreneurship outcomes and access to critical resources (Block, Fisch, \& van Praag, 2017).

Empirical research has shown that there are interrelated effects between economic development and entrepreneurship, as there are between the innovation and economic outcomes. For instance, Wennekers, van Wennekers, Thurik and Reynolds (2005) found a positive correlation between entrepreneurial activity and innovative capacity in developed countries. An increased level of entrepreneurial activity can lead to an enhanced ability to 'produce a stream of commercially relevant innovations' (Wennekers et al., 2005, p. 297), and, therefore, to higher productivity and knowledge spillovers (Acs et al., 2009; Acs, Audretsch, \& Lehmann, 2013). On the other hand, Aghion and Howitt (1992) and Carree and Thurik (2008) found that an innovative entrepreneurship's impact on economic development is often and that the variables used to establish this impact are not understood well enough or convincingly determined. Additionally, Barro (1991) considers that in cross-sectional regression analysis, developed countries tend to register lower growth rates in comparison to the developing or emerging economies and, therefore, the interpretation of the results can lead to mixed effects.

The mixed evidence is also in part due to a lack of consensus about the definition of entrepreneurship and different empirical proxies. Most empirical measurements use the self-employment rate or business ownership rate to capture the risk-taking aspect of entrepreneurship, as emphasized in Knight (1921), but very few of them capture the defining feature of entrepreneurship in Schumpeter (1934) - innovation. Therefore, we can say that many researchers use entrepreneurship proxies that ignore innovation, although only a fraction of these so-called entrepreneurs innovates (Low \& Isserman, 2015). Hence, entrepreneurs are differentiated, being seen as managerial and innovative. Moreover, some studies (e.g., Wong, Ping, \& Erkko, 2005; Acs, 2006; Shane, 2009; Global Entrepreneurship Research Association, 2017) suggest that the motivation for becoming entrepreneurs in different countries and industries is different. In countries with higher levels of economic development, individuals are driven to become entrepreneurs by a perceived business opportunity or by the motivation for self-improvement; while in countries with lower development levels, entrepreneurs are mostly necessity-driven individuals who find themselves with no other options for 
work than self-employment. The improvement opportunity-to-necessity entrepreneurship ratio, or motivation Index, as it is entitled by the Global Entrepreneurship Research Association in its Global Entrepreneurship Monitor (GEM), was used by some authors as the indicator to determine the relationship between the entrepreneurship ratio and GDP per capita (Acs, 2006; Szabo \& Herman, 2012). In order to evaluate the effects of innovative entrepreneurship on economic growth, Wong et al. (2005) embedded in a model the GEM dataset for 2002 (total early age entrepreneurs (TEA), opportunity TEA, necessity TEA, and high growth potential TEA). Szabo \& Herman (2012) also use the GEM dataset in their study, but their analysis, however, is limited to bivariate correlations covering short term periods, with no attempt to control for other factors.

To sum up, the economic literature has yielded mixed results regarding the effects of (innovative) entrepreneurship on economic growth. Most of the studies have acknowledged the salient role of entrepreneurship in driving innovation, economic growth, and welfare (in addition to its effect on job creation), but also a vice-versa effect. Innovation may impact entrepreneurial activity and its outcomes. Therefore, it can be contended that there are interrelations between economic growth and entrepreneurship, as well as between innovative entrepreneurship and economic outcome. Additionally, the literature on innovative entrepreneurship is somewhat scattered across the innovation and entrepreneurship disciplines, and not much cross-referencing occurs (Block, Fisch, \& van Praag, 2017). Also, there is no clear empirical evidence on the effect of innovative entrepreneurship on the economic growth of EU countries. The benefits of entrepreneurship and innovation on economic growth have sparked increased interest, not only in research but also in policy-making. Consequently, more and more governments have developed and adopted programs and policies that aim to foster entrepreneurship and spur innovation. Not by chance, entrepreneurship and innovation rely on the core of the European Union's development strategy - Europe 2020. According to the European Commission, Europe's economic growth and jobs depend on its ability to support the growth of enterprises. By promoting entrepreneurship, the creation of new companies is encouraged, which, consequently, foster job creation, open up new markets, and nurture new skills (European Commission, 2015).

In the given context, the present paper's objective is to assess the effects of innovative entrepreneurship on economic growth, taking the European Union (EU) member countries as a case study. 


\section{RESEARCH METHODS}

Given the nature of contemporary highlights of the literature review and the stated research objective, in this paper, we want to test a model that captures the new or young and innovative firms, as aspects of innovative entrepreneurship and determinants of economic growth rates. This approach is in line with the view of several researchers (Wennekers \& Thurik, 1999; Davidsson, 2003; Wong et al., 2005, etc.) that consider business creation and innovation as separate aspects of entrepreneurship and, therefore, determinants of economic growth in its macroeconomic formulation. Both strands of the economic theory, the horizontal innovation growth models (Romer, 1990) and the vertical innovation growth models (Schumpeter 1934; Aghion and Howitt, 1992, etc.), acknowledge the salient role of innovation in accelerating economic growth. Following these theories, the first hypothesis of the present paper is:

H1: EU member countries with higher levels of innovation performance have higher economic growth rates.

To gauge the innovation performance of the EU countries, the Summary Innovation Index (SII) dataset from the European Innovation Scoreboard is used. Several empirical studies suggest that not all new firms contribute equally to economic growth. That is why, in order to assess the effects of innovative firms, the share of SMEs introducing product or process innovations to one of their markets (percentage of SMEs) and the share of the SMEs introducing marketing or organizational innovations (percentage of SMEs) are embedded in the model. Technological innovation is a key ingredient to innovation in manufacturing activities. Higher shares of technological innovators should reflect higher levels of innovation activities. Many firms, in particular in the service sectors, innovate through other non-technological forms of innovation. Examples of these are marketing and organizational innovations. The data about the SMEs introducing technological and non-technological innovations are taken from the European Innovation Scoreboard dataset. GDP data are taken from the Eurostat database.

The recent findings supporting the idea that mostly young innovative firms are those contributing the most to economic growth, lead us to the idea to use the data on Total Early-stage Entrepreneurial Activity (TEA), provided by the Global Entrepreneurship Monitor, to measure those new or young firms. According to the Global Entrepreneurship Monitor, TEA measures the percentage of the adult population between the ages of 18 and 64 years who are in the process of starting a business (a nascent entrepreneur) or are 
owner-managers of a new business which is less than 42 months old (GEM, 2016 -2017). Therefore, the next hypothesis to be tested is:

H2: Countries with higher total early-stage entrepreneurial activity register faster growth rates.

The motivation driving the decision to become an entrepreneur is also taken into account, in order to see if there is a correlation between the level of economic development and their motivation index (percentage of those involved in TEA that is improvement-driven opportunity motivated, divided by the percentage of TEA that is necessity-motivated). Therefore, the $3^{\text {rd }}$ and 4th hypotheses to be tested are:

H3: The motivation to become an entrepreneur is directly determined by the level of development.

Furthermore, as innovation is the key ingredient in the success of entrepreneurial activity and innovative entrepreneurs tend to contribute more substantially to economic growth, the final hypothesis to be tested is:

H4: Countries with higher economic development levels tend to have more innovative entrepreneurs.

These hypotheses are tested in a data set of $28 \mathrm{EU}$ member countries over the period 2010-2016. The model used in this paper for testing the established hypotheses represents an extension of the neo-classical growth model. Because of the relatively small sample of cases, we have been quite parsimonious in selecting the independent variables. Therefore, the control variables in our model are: 1) Lagged GDP per person employed (to test the concept of relative convergence, where the coefficient is expected to be negative, consistent with the theory), and 2) Growth in Capital per worker. The variables of interest predictors are Total Early-stage Entrepreneurial Activity (TEA), SMEs introducing technological innovations and SMEs introducing non-technological innovations. These independent variables are embedded decidedly as determinants or predictors of economic growth, representing characteristics of innovative entrepreneurship and being considered as augmenting factors of production. Consequently, TEA represents a form of entrepreneurial capital, while technological and non-technological innovations measure knowledge capital.

Therefore, the generic equation of the regression model is:

$$
\Delta \ln \left(y_{i, t}\right)=\alpha_{0, i}+\alpha_{1} \ln \left(y_{i, t-1}\right)+\alpha_{2} \Delta \ln (K / L)_{i, t}+\beta_{1} \mathrm{TEA}_{i, t}+\beta_{2} \mathrm{TI}_{i, t}+\beta_{3} \mathrm{NTI}_{i, t}+\varepsilon_{i, t}
$$


Where:

- $\Delta \ln \left(y_{i, t}\right)$ is the Rate of Economic Growth (the dependent variable) being measured by the increase in the real GDP growth per worker of country $i$, in the time period $t$. GDP per worker captures economic growth due to productivity gains, after controlling for differences in labor participation rates across EU member countries. The GDP data and the number of persons employed in the $28 \mathrm{EU}$ member countries are taken from Eurostat;

- $\ln \left(y_{i, t-1}\right)$ represents the Lagged Real GDP per person employed in logarithmic form. This variable was embedded into the equation to control the "conditional beta-convergence" effect, which occurs when developing economies tend to grow faster than developed countries. This is in line with the suggestion of Barro (1991), according to which, in cross-country regression models, rich economies tend to register lower economic growth rates;

- $\Delta \ln (K / L)_{i, t}$ is the growth rate in the Capital per worker of the country $i$, in the time period $t$. Growth in capital per worker is included to control the economic growth that is determined by the increase of capital as a factor of production. Data for Gross Fixed Capital Formation (GFCF) for EU member countries is obtained from the Eurostat database;

- TEA - Total Early-stage Entrepreneurial Activity - measures new firms' creation or the percentage of the adult population between the ages of 18 and 64 years who are in the process of starting a business or who have just started a business which is less than 42 months old. TEA is used to capture the new and young firms that, according to several studies mentioned above, contribute the most to economic growth;

- TI - TechInno stands for technological innovation, being measured by the percentage of firms that introduced either a product and/or a service that is new to the market or to the firm itself. According to the OECD (2009), product innovation is the introduction of a good or service that is new or has significantly improved characteristics or intended uses; a process innovation refers to the implementation of a new or significantly improved production or delivery method. The data regarding the percentage of SMEs that introduced product or process innovations that are new to the market were taken from the European Innovation Scoreboard database;

- NTI - Non-Techlnno stands for the share of firms who introduced a new marketing innovation and/or organizational innovation to one of their markets. Besides technological innovations, many firms, especially in the tertiary sector, have a tendency to introduce marketing and/or organizational 
innovations. This indicator tries to gauge the share of SMEs that innovate through non-technological innovations;

- $\alpha_{0, \mathrm{i}}$ is the constant, standing for the individual effects of every country;

- $\alpha_{1}, \alpha_{2}$ are coefficients for control variables;

- $\beta_{1}, \beta_{2}$ are coefficients for innovation activity;

- $\varepsilon_{\mathrm{i}, \mathrm{t}}$ is the error term.

For empirical estimation of the model, data presented in the form of natural logarithm were used. Therefore, the growth rate is presented as:

$$
\Delta \ln \left(y_{t}\right)=\ln \left(y_{t}\right)-\ln \left(y_{t-1}\right)=\left(y_{t}-y_{t-1}\right) / y_{t-1}
$$

For the regression analysis model panel data were used, covering all EU member countries for the period 2010-2016. The timeframe was limited to this period due to the lack of data for all analyzed countries in earlier years (especially for TEA). Additionally, the empirical research relies on a statistical method, using Stata software for panel data analysis.

\section{ANALYSIS AND RESULTS}

Overall, the constructed equation seems to be reasonably defined, with significant $\mathrm{F}$ and $\mathrm{t}$ statistics. Collinearity statistics show that there is no problem of multicollinearity between independent variables, except the causality between TechInno and Non-TechInno variables (See appendix 1). This could be explained by the fact that the firms that introduce the product and/or process innovations might be the same firms that introduce organizational or marketing innovations. Nevertheless, as soon as the NonTechInno is not statistically significant in the regression analysis, we still maintained it in the model as an independent variable, just to test its role in economic growth so far.

Table 1 exhibits the result of the four regressions using three different estimation methods (Pool Ordinary Least Squares, random effects, fixed effects and GMM).

After performing the Hausman test, we found that fixed effects (FE) regression is the model that is appropriate for our analysis. The difference in the coefficients is systematic because the $P$ value for the chi2 test is less than 0.05 . This means that the fixed effects (FE) model is preferable over the random effects (RE) model.

Fixed effects explore the relationship between predictor and outcome variables within an entity (EU countries in our case). Each country has its own individual characteristics that may or may not influence the predictor 
variables. When using fixed effects, we assume that something within the individual may impact or bias the predictor or outcome variables and we need to control for this. This is the rationale behind the assumption of the correlation between a country's error term and predictor variables. Fixed effects remove the effect of those time-invariant characteristics so we can assess the net effect of the predictors on the outcome variable. Another important assumption of the fixed effect model is that those time-invariant characteristics are unique to the individual and should not be correlated with other individual characteristics. Each country is different. Therefore the country's error term and the constant (which captures individual characteristics) should not be correlated with the others.

The regression analyses show that the Total Early-stage Entrepreneurial Activity is not statistically significant. This result corroborates with the findings of Carree et al. (2007) that suggest that entrepreneurship (expressed by the self-employment rate) has insignificant effects on economic growth. Taking into consideration that in the initial estimation model (see appendix 2), not all variables are statistically significant, we decided to re-estimate the model, as presented in Table 1.

The control variables proved to be significant and explain around $67 \%$ of national economic growth in the $28 \mathrm{EU}$ member countries. The correlation of Lagged GDP per person employed () confirms the conditional convergence effect. Additionally, as was expected, growth in capital per worker has a positive convergence effect and is statistically significant. The TI variable proves to be statistically significant. However, it has a relatively small influence on the dependent variable (Real GDP Growth per worker), registering values of $-0,002 \%$.

The interpretation of data says that a 1 percentage point increase in the share of SMEs introducing technological innovations results in a $0,002 \%$ decrease in the growth of real GDP per worker, which is in contradiction with the theory, but not with the results of some studies (Wong et al., 2005; Carree et al., 2007). This result might be explained by the argument that the new product and/or process innovations introduced by European firms required substantial investments and did not prove to have a big impact on economic growth. Also, taking into consideration that the analysis covers a relatively short period of time, it might be argued that these innovations would result in positive effects on economic growth in the long run, taking firms a longer time to recover their investments and increase their productivity. 
Table 1. Results of estimation models

\begin{tabular}{|c|c|c|c|c|}
\hline & $\begin{array}{l}\text { (Pool OLS) } \\
\Delta \ln \left(y_{i, t}\right)\end{array}$ & $\begin{array}{l}\text { (RE) } \\
\Delta \ln \left(y_{i, t}\right)\end{array}$ & $\begin{array}{l}\text { (FE) } \\
\Delta \ln \left(y_{i, t}\right)\end{array}$ & $\begin{array}{l}\text { (GMM) } \\
\Delta \ln \left(\mathbf{y}_{\mathrm{i}, \mathrm{t}}\right)\end{array}$ \\
\hline $\ln \left(y_{i, t-1}\right)$ & - & $-0.003^{*}$ & $-0.177^{* * *}$ & $-0.143^{* *}$ \\
\hline Std error & & $(0.002)$ & $(0.038)$ & $(0.125)$ \\
\hline Prob. & & 0.101 & 0.000 & 0.050 \\
\hline$\Delta \ln (\mathrm{K} / \mathrm{L})_{\mathrm{i}, \mathrm{t}}$ & $0.274^{* * *}$ & $0.276^{* * *}$ & $0.175^{* * *}$ & $0.258^{*}$ \\
\hline Std error & $(0.022)$ & $(0.041)$ & $(0.024)$ & $(0.084)$ \\
\hline Prob. & 0.000 & 0.000 & 0.000 & 0.101 \\
\hline $\mathrm{TI}$ & - & - & $-0.002 * *$ & 0.002 \\
\hline Std error & & & $(0.001)$ & $(0.003)$ \\
\hline Prob. & & & 0.046 & 0.573 \\
\hline NTI & $-0.001 * * *$ & $-0.001 * *$ & $0.001^{*}$ & $0.004^{* * *}$ \\
\hline Std error & $(0.000)$ & $(0.000)$ & $(0.000)$ & (0.001) \\
\hline Prob. & 0.000 & 0.040 & 0.110 & 0.005 \\
\hline cons & $0.040 * * *$ & $0.049 * * *$ & $0.703 * * *$ & - \\
\hline Std error & $(0.000)$ & $(0.000)$ & $(0.142)$ & \\
\hline Prob. & 0.001 & 0.005 & 0.000 & \\
\hline $\mathrm{N}$ & 154 & 154 & 154 & 154 \\
\hline R-sq & 0.464 & 0.470 & 0.673 & J-statistic 21.9 \\
\hline
\end{tabular}

Standard errors in parentheses

$* \mathrm{p}<0.10, * * \mathrm{p}<0.05, * * * \mathrm{p}<.01$

The rescue packages launched by the European countries' governments to "save" their hard-hit-by-the-crisis economies, led to a slight recovery in 2010 but was followed by a contraction in 2012. After then, positive growth rates were registered, except for the last year of the analysis. These findings are in line with the Eurostat (2017) data regarding labor productivity per person employed, suggesting that labor productivity differs across the countries and sectors, but increased over the years (except 2012) in almost all EU member countries, except Greece, Italy, Croatia, Luxembourg and Finland (no data are available for Malta) (Eurostat, 2017). The brief analysis of the summary statistics, confirm the above-mentioned statement.

Taking into consideration that in our model (1) there is a lagged dependent variable and individual effects vary across countries, we should consider the dynamic panel bias. In order to mitigate the dynamic panel bias, we use Generalized Method of Moments (GMM). In our case, we employ the Arellano Bond method to transform all the elements of the model into the first differences. As instruments for explaining the variables, their values for previous periods of time (i.e., t-2 period) were used. The results are represented in Table 1, column (GMM). In this model, the most significant factors for determining the development of economic growth is the growth rate of Gross Capital Formation per employed person () and non-technological innovations (NTI). When evaluating a dynamic model using GMM, a larger number of instrumental variables are included in the model. In the GMM 
model used, there may be a correlation between the first differences of error $(\varepsilon)$ and regressors (predictors), which can lead to biased, inefficient and inconsistent estimates. As a result, additional variables are included in the model, including late differences for the dependent variable and a specific set of instrumental variables. To verify the necessity of including additional conditions, a Sargan test was performed, which confirmed that the hypothesis about the fulfillment of additional moment conditions is accepted.

Therefore, the first hypothesis, that EU member countries with higher innovation levels have higher economic growth rates, is not fully supported by our model, the variables measuring the technological innovations (TI), even if it has a relatively positive effects on our dependent variable, it is not statistically significant. However, when running bivariate correlations between the summary innovation index and the GDP/capita of the EU member countries for 2016, we have found a strong and significant causality, with a Pearson coefficient of $+0,793$ (see Figure 2).

As shown in Figure 2, innovative performance is a driver of economic development in EU member countries. These findings attest our supposition and suggest that countries with a higher level of economic development are characterized by an increased level of innovation performance, and, therefore, highlight the need of the developing countries to put more effort into this area and spur innovative firms' development.

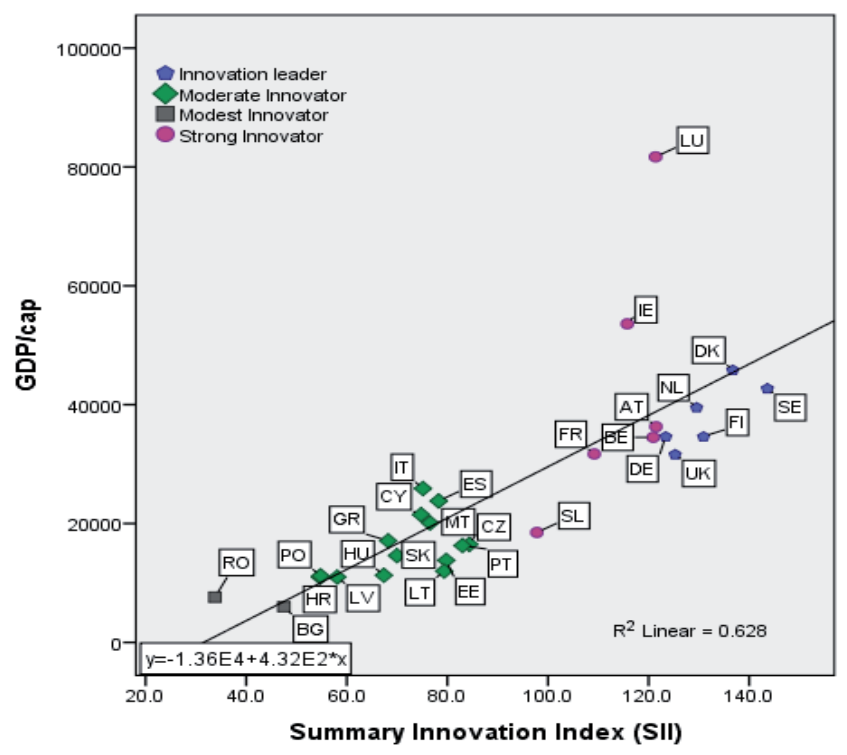

Figure 2. Correlation between the GDP/capita and Innovation performance of EU member countries, 2016 
The model does not support our second hypothesis, that countries with higher TEA register faster growth rates, the variable measuring it being insignificant. The insignificance of TEA could be explained by the fact that the analysis covers countries with different levels of development and TEA depends on the state of development of each economy. Therefore, countries with lower levels of economic growth tend to have fewer newly created firms. Moreover, new firms are created in the countries in which the government supports and promotes firms' creation. Hence, it is directly influenced by the business and entrepreneurship policies, financial tools and programs that these governments promote, which, in most of the cases, is consistent with the level of development. Moreover, advanced countries place a larger focus on the quality of entrepreneurship rather than its respective quantity (Peris-Ortiza, Ferreirab, \& Fernandesc, 2017). This might also be explained by the fact that the types of entrepreneurs vary across countries. In the developed countries the entrepreneurs are most likely to be of a Schumpeterian type, while in developing countries most of them are shopkeepers (Block, Fisch, \& van Praag, 2017). Consequently, it is clear that EU member countries need friendlier and more efficient new firms' creation policies, as well as SME-supporting tools.

Additional regression analyses with types of TEA motivations resulted in insignificant correlations for Opportunity TEA and Necessity-driven TEA (see appendix 3). However, the signs of the coefficients (the Pearson coefficient for Opportunity-driven TEA is +0.42 , while for the Necessitydriven TEA it is -0.55) suggest that entrepreneurs' motivation is consistent with the development level of the economy (entrepreneurs from countries with a higher development level are more opportunity and improvementdriven motivated, while entrepreneurs from countries with lower levels of economic development, tend to be Necessity-driven motivated). Hence, these findings support the third established hypothesis, according to which the motivation to become an entrepreneur is directly determined by the level of development (see Figure 3), and they corroborate with the findings of Birch et al. (1987), Shane (2009) and Andreeva, Simon, Karkh and Glukhikh (2016) who contend that opportunity-driven entrepreneurs are most likely to contribute to economic growth acceleration.

TEA (especially Opportunity-driven TEA) has positive effects on entrepreneurship, while entrepreneurship could contribute to innovation creation, this idea indeed being supported by various studies (Wennekers \& Thurik, 1999; Wennekers et al., 2005; Wong et al., 2005; Welter \& Lasch, 2008; Peris-Ortiza, et al., 2017). In the last years, the Global Entrepreneurship Report started to calculate the innovation level of Total Early-stage Entrepreneurial Activity. This indicator gauges the percentage of those involved in TEA who have indicated that their product or service is new to at least some customers 
and that few, or no, firms offer the same product/service. The TEA innovation level shows a significant and positive correlation with the GDP per capita in 22 EU member countries (for 6 EU countries, TEA innovation levels data are not available) (see Figure 4), this being proved by the relatively high Pearson coefficient (+0.732).

Countries with a higher GDP/cap and innovation performance tend to have more innovative entrepreneurs. This supports our last hypothesis and might be explained by the positive relationship between innovation and innovation-friendly implementation policies and the state of economic development of the countries (Peris-Ortiza et al., 2017).
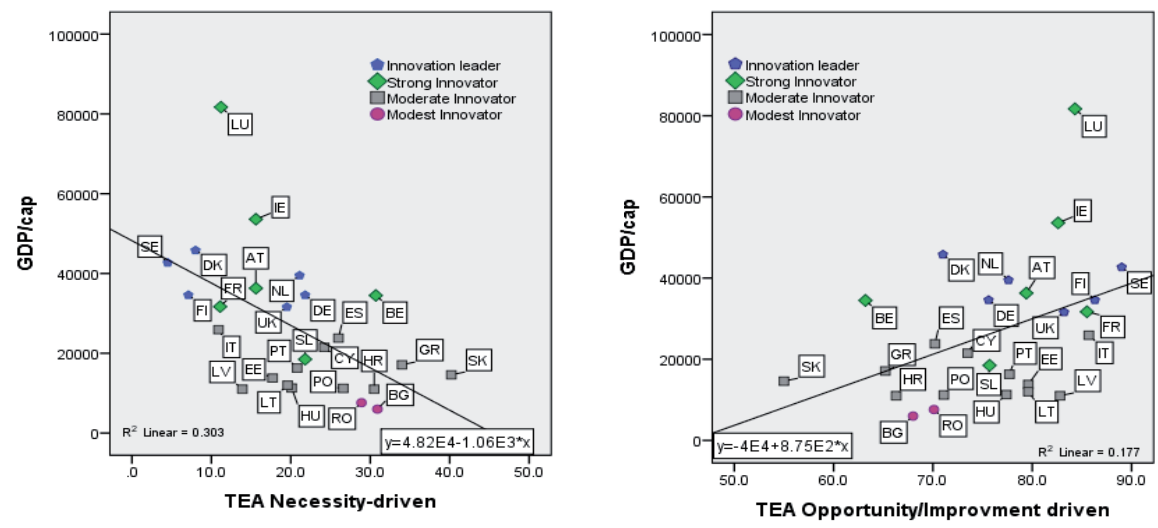

Figure 3. The correlations between the GDP/cap and motivation of becoming entrepreneurs in EU member countries, 2016

Advanced countries allocate large amounts for innovation and entrepreneurial policies and the tools to implement them, being expected to influence the quality of entrepreneurship and economic growth. For instance, Fritsch and Mueller (2007) found that the regional variation in the innovation and entrepreneurial climate in Germany explains the overall regional business development performance. Consequently, we may suggest that in order to foster economic growth and spur entrepreneurship and innovation creation, EU countries need efficient entrepreneurship and innovation policies. 


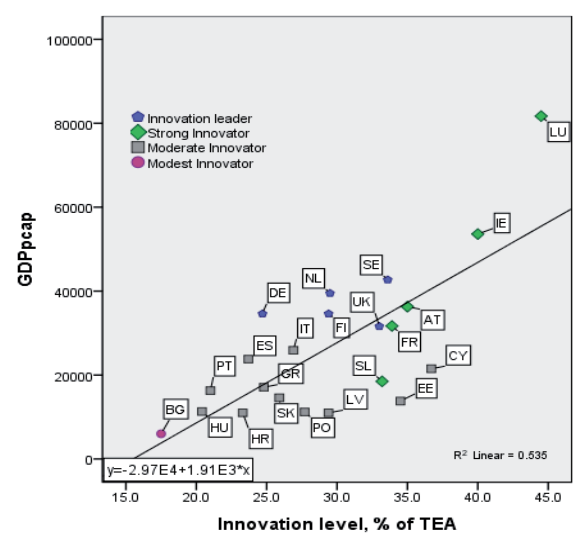

Correlations

\begin{tabular}{|l|r|r}
\hline Pearson & GDPpcap & GDPpap \\
Correlation & TEA, \% of adult pop & 1.000 \\
& Innovation level, \% of TEA & .042 \\
\multirow{3}{*}{ Sig. (1-tailed) } & GDPpcap &. \\
& TEA, \% of adult pop & .426 \\
& Innovation level, \% of TEA & .000 \\
\hline \multirow{2}{*}{ N } & GDPpcap & 22 \\
& TEA, \% of adult pop & 22 \\
& Innovation level, \% of TEA & 22 \\
& & \\
& & \\
\end{tabular}

Figure 4. The correlations between the GDP/cap and TEA Innovation level in EU member countries, 2016

\section{CONCLUSION}

The results of the regression analysis suggest that a higher degree of entrepreneurship, especially in new firms' creation, does not contribute substantially to accelerated economic development (the TEA variable being insignificant). Taking into account the timeframe of the analysis, these results might be explained by the fact that firms tend to contribute to economic growth in the long-run, rather than generating short-term effects. Another reason could rely on several other factors of entrepreneurship (rather than firms' creation) that might accelerate economic growth. Another finding of the paper suggests that entrepreneurs' motivation is consistent with the development level of the economy. Results show that innovative entrepreneurs (being measured by the TEA innovation level) are more present in countries with a higher development level and higher incomes, being motivated to become entrepreneurs as they see an improvement opportunity. This also suggests that policies promoted by the governments of these countries are more efficient (fund-intensive) in building attractive and productive entrepreneurial and innovation climates. This conclusion is also supported by the results of the regression analysis, suggesting that opportunity or improvement-driven motivation is positively correlated with the level of development. The interrelation of the above-mentioned ideas, gives us support to contend that the most significant contribution to economic growth is made by "emerging" firms, rather than new firms in general (Birch et al., 1987; Andreeva et al., 2016). 
The findings of this research help us conclude that the differences in EU member states' economic growth rates could be explained by the diffusion of new firms with high growth potential. Still these countries undertake other forms of entrepreneurial activity, but these do not differentiate countries with varying growth rates. This nurtures the idea that entrepreneurship and innovation policies, which are more focused on efficiency, are more appropriate than those based on quantity.

Moreover, taking into consideration that entrepreneurship and innovation are facets of innovative entrepreneurship, the need for a holistic approach towards innovation and entrepreneurship policies is imperative (Crudu, 2017). However, the high complexity of the governance of EU innovation policy, the overlap between funding instruments and too many decision-makers, lead to outcomes that fall below EU expectations (Anvert, Granieri, \& Renda, 2010). The policy and institutional environment is an important determinant of innovative behavior. Government support for innovation is important. There should be the promotion of entrepreneurship in general, and policies ought to be framed to focus on increasing innovative activities among existent, as well as new growing firms. The policy may aim to correct market failures (e.g., failures arising from informational imperfections and positive externalities of knowledge creation) that negatively affect the performance of innovative entrepreneurs. Therefore, the soundness of government intervention's foundations and achievements need to be scrutinized ex-ante and ex-post.

Having this in mind, we aim to shed light in our future research on the role of the policies adopted by governments in supporting innovative entrepreneurship and their nature. Taking into consideration that the quality of innovative entrepreneurs does not depend only on the quality of policies and their manner of implementation, further empirical research should also approach the identification of the correlation between entrepreneurial education, entrepreneurship performance and economic growth; establishing a benchmarking tool for measuring innovative entrepreneurs and identifying industries with higher concentrations of innovative firms, that mostly contribute to economic growth acceleration.

Additionally, further research is needed to consider more carefully the impact of TEA on innovation performance and the economic growth of countries, which might be explained by factors that fall beyond the scope of this study. 


\section{Acknowledgments}

The contribution of Dr. Rodica Crudu to this paper was supported by the project Jean Monnet Chair in EU Policies towards Innovation, Creativity and Entrepreneurship/ EU2INNO, ref. nr. 2016/2332-574680-EPP-1-20161MD-EPPJMO-CHAIR, co-funded by the Erasmus+ Programme of the European Union.

\section{References}

Acs, Z.J., Åstebro, T., Audretsch, D., \& Robinson, D.T. (2016). Public policy to promote entrepreneurship: A call to arms. Small Business Economics, 47(1), 1-17.

Acs, Z.J., Audretsch, D.B., \& Lehmann, E.E. (2013). The knowledge spillover theory of entrepreneurship. Small Business Economics, 41(4), 757-774.

Acs, Z.J., Braunerhjelm, P., Audretsch, D., \& Carlsson, B. (2009). The knowledge spillover theory of entrepreneurship. Small Business Economics, 32(1), 15-30.

Acs, Z.J., \& Armington, C. (2004). Employment growth and entrepreneurial activity in cities. Regional Studies, 38(8), 911-27.

Acs, Z.J., \& Armington, C. (2003). Endogenous growth and entrepreneurial activity in cities. Washington DC: Center for Economic Studies, U.S. Bureau of the Census, CES 03-02.

Aghion, Ph., \& Howitt, P. (1992). A model of growth through creative destruction. Econometrica, 60(2), 323-51.

Andreeva, E.L., Simon, H., Karkh, D.A., \& Glukhikh, P.L. (2016). Innovative entrepreneurship: A source of economic growth in the region. Ekonomika Regiona (Economy of Region), 12(3), 899-910.

Anvert, M., Granieri, M., \& Renda, A. (July 2010). A new approach to innovation policy in the European Union. Innovation policy: Boosting EU competitiveness in a global economy. CEPS Task Force Report. Retrieved from http://aei.pitt.edu/14482/

Audretsch, D.B., Bönte, W., \& Keilbach, M. (2008). Entrepreneurship capital and its impact on knowledge diffusion and economic performance. Journal of Business Venturing, 23(6), 687-698.

Audretsch, D.B., \& Fritsch, M. (2002). Growth regimes over time and space. Regional Studies, 36, 113-124.

Audretsch, D.B., \& Thurik, R. (2000). Capitalism and Democracy in the 21st Century: From the Managed to the Entrepreneurial Economy. Journal of Evolutionary Economics, 10(1), 17-34.

Audretsch, D.B. (1995). Innovation and Industry Evolution. Cambridge, MA: MIT Press.

Barro, R. (1990). Government spending in a simple model of endogenous growth. Journal of Political Economy, 82(6), 1095-1117. 
Barro, R. (1991). Economic growth in a cross-section of countries. Quarterly Journal of Economics, 106, 407-44.

Blanchflower, D.G. (2000). Self-employment in OECD countries. Labour Economics, 7, 471-505.

Birch, D.L. (1987). Job Creation in America: How Our Smallest Companies Put the Most People to Work. New York: Free Press.

Block, J.H., Fisch, C.O., \& van Praag, M. (2017). The Schumpeterian entrepreneur: A review of the empirical evidence on the antecedents, behaviour and consequences of innovative entrepreneurship. Industry and Innovation, 24(1), 61-95.

Cameron, G. (1996) Innovation and economic growth. CEPDP (277). Centre for Economic Performance. London, UK: London School of Economics and Political Science.

Carree, M.A., \& Thurik, A.R. (2008). The lag structure of the impact of business ownership on economic performance in OECD countries. Small Business Economics, 30(1), 101-110.

Carree, M.A., van Stel, A., Thurik, A.R., \& Wennekers, S. (2007). The relationship between economic development and business ownership revisited. Entrepreneurship \& Regional Development, 19, 281-291.

Caves, R.E. (1998). Industrial organization and new findings on the turnover and mobility of firms. Journal of Economic Literature, 36, 1947-1982.

Crudu, R. (2017). The role of innovation and creativity in shaping the future of EU. Proceedings of the International Conference on European Financial Regulation (pp. 202-214), Alexandru Ioan Cuza University of lasi, 18-20 May 2017. Retrieved from http://eufire.uaic.ro/wp-content/ uploads/2017/08/volum_EUFIRE_2017_docx.pdf

Davidsson, P. (2003). The domain of entrepreneurship research: Some suggestions. In J. A. Katz \& D. Shepherd (Eds.), Cognitive Approaches to Entrepreneurship Research. Advances in Entrepreneurship, Firm Emergence and Growth (pp. 315-372). UK: Emerald Group Publishing Limited.

Dolfsma, W., van der Velde, D. (2014). Industry innovativeness, firm size, and entrepreneurship: Schumpeter Mark III?. Journal of Evolutionary Economics, 24(4), 713-736.

ECD. (2009). Innovation within companies. OECD Science, Technology and Industry Scoreboard 2009. OECD Publishing. Retrieved from http:// dx.doi.org/10.1787/sti_scoreboard-2009-40-en

European Commission. (2015). Promoting Entrepreneurship. Retrieved from http:// ec.europa.eu/growth/smes/promoting-entrepreneurship/index_en.htm

Eurostat. (2017). National accounts and GDP: Statistics explained. Retrieved 12 November, 2017, from http://ec.europa.eu/eurostat/statisticsexplained/ index.php/National_accounts_and_GDP\#Labour_productivity

Evans, D.S., \& Leighton L.S. (1989). Some empirical aspects of entrepreneurship. American Economic Review, 79, 519-535. 
Fagerberg, J., Mowery, D.C., \& Nelson, R. (2009). (Eds.). The Oxford Handbook of Innovation. Oxford: Oxford University Press. http://doi.org/10.1093/ oxfordhb/9780199286805.001.0001

Folster, St. (2000). Do entrepreneurs create jobs? Small Business Economics, 14(2), 137-48.

Fritsch, M., \& Pamela, M. (2004). Effects of new business formation on regional development over time. Regional Studies, 38(8), 961-75.

Haltiwanger, J., Jarmin, R.S., \& Miranda, J. (2013). Who creates jobs? Small versus large versus young. Review of Economics and Statistics, 95(2), 347-361.

Henrekson, M., \& Johansson, D. (2010). Gazelles as job creators: A survey and interpretation of the evidence. Small Business Economics, 35(2), 227-244.

Holmes, T.J., \& Schmitz, J.A. (1990). A theory of entrepreneurship and its application to the study of business transfers. Journal of Political Economy, 98, 265-294.

GlobalEntrepreneurship Research Association (2017). Global Entrepreneurship Monitor - 2016-17. Executive Report [online]. London, UK: Babson College, London Business School, Universidad del Desarrollo, Universiti Tun Abdul Razak, Tecnológico de Monterrey. Retrieved from https:// www.gemconsortium.org/report/49812

Griliches, Z. (1990). Patent statistics as economic indicators: A survey. Journal of Economic Literature, 28, 1661-1707.

Koellinger, P. (2008). Why are some entrepreneurs more innovative than others? Small Business Economics, 31(1), 21-37.

Kressel, H., \& Lento, T.V. (2012). Entrepreneurship in the Global Economy: Engine for Economic Growth. Cambridge: Cambridge University Press.

Low, S.A, \& Isserman, A.M. (2015). Where are the innovative entrepreneurs? Identifying innovative industries and measuring innovative entrepreneurship. International Regional Science Review, 38(2), 171-20.

Lucas, R. (1988). On the mechanics of economic development. Journal of Monetary Economics, 22, 3-42.

Naudé, W. (Ed.) (2011). Entrepreneurship and Economic Development, New York: Palgrave Macmillan.

Neumark, D., Wall, B., \& Zhang, J. (2011). Do small businesses create more jobs? New evidence for the United States from the national establishment time series. The Review of Economics and Statistics, 93(1), 16-29.

Peris-Ortiza, M., Ferreirab, J.M., \& Fernandesc, C.I. (2017). Do total earlystage entrepreneurial activities (teas) foster innovative practices in OECD countries? Technological Forecasting \& Social Change., 129, 176-184. http://dx.doi.org/10.1016/j.techfore.2017.07.005

Pontus, B., Acs, Z.J., Audretsch, D., \& Carlsson, B. (2010). The missing link: Knowledge diffusion and entrepreneurship in endogenous growth. Small Business Economics, 34(2), 105-125.

Romer, P. (1986). Increasing returns and long run growth. Journal of Political Economy, 94, 1002-37. 
Romer, P. (1990). Endogenous technological change. Journal of Political Economy, 98, S71-S102.

Schumpeter, J.A. (1934). The Theory of Economic Development. Cambridge MA: Harvard University Press.

Shane, S.A. (2003). A General Theory of Entrepreneurship. Cheltenham: Edward Elgar.

Shane, S. (Ed.). 2005. Economic Development through Entrepreneurship. Government, University and Business Linkages. Cheltenham: Edward Elgar.

Shane, S. (2009). Why encouraging more people to become entrepreneurs is bad public policy. Small Business Economics, 33(2), 141-149.

Solow, R.M. (1956). A contribution to the theory of economic growth. Quarterly Journal of Economics, 70, 65-94.

Sutton, J. (1997). Gibrat's legacy. Journal of Economic Literature, 35, 40-59.

Szabo, Z.K., \& Herman, E. (2012). Innovative entrepreneurship for economic development in EU. Procedia Economics and Finance, 3, 268 - 275.

Uppenberg, K. (2009). Innovation and economic growth. EIB Papers, 14(1), 10-35.

van Praag, C.M., \& Versloot, P.H. (2007). What is the value of entrepreneurship? A review of recent research. Small Business Economics, 29(4), 351-382.

Welter, F., \& Lasch, F. (2008). Entrepreneurship research in Europe: Taking stock and looking forward. Entrepreneurship Theory and Practice, 32, 241-248.

Wennekers, S., \& Thurik, R. (1999). Linking entrepreneurship and economic growth. Small Business Economics, 13(1), 27-56.

Wennekers, S., van Wennekers, A., Thurik, R., \& Reynolds, P. (2005). Nascent entrepreneurship and the level of economic development. Small Business Economics, 24(3), 293-309.

Wong, P.K., Ping, H.Y., \& Erkko, A. (2005). Entrepreneurship, innovation and economic growth: Evidence from GEM data. Small Business Economics, 24 (3), 335-350. 


\section{Appendixes}

Appendix 1. Correlation of the regression model's variables

\begin{tabular}{lllllll}
\hline & \multicolumn{1}{c}{$\Delta \ln \left(\mathrm{y}_{\mathrm{i}, \mathrm{t}}\right)$} & $\ln \left(y_{i, t-1}\right)$ & $\Delta \ln (K / L)_{i, t}$ & $\mathrm{TEA}$ & $\mathrm{TI}$ & $\mathrm{NTI}$ \\
\hline$\Delta \ln \left(\mathrm{y}_{\mathrm{i}, \mathrm{t}}\right)$ & 1 & & & & \\
$\ln \left(y_{i, t-1}\right)$ & 196 & & & & \\
& -0.115 & 1 & & & & \\
& 0.1085 & & & & & \\
$\Delta \ln (K / L)_{i, t}$ & 196 & 196 & & & & \\
& 0.626 & 0.0617 & 1 & & & \\
TEA & 0 & 0.3902 & & & & \\
& 196 & 196 & 196 & & & \\
& 0.1733 & -0.3933 & 0.2158 & 1 & & \\
TI & 0.031 & 0 & 0.007 & & & \\
& 155 & 155 & 155 & 155 & & \\
& -0.1705 & 0.7506 & -0.0036 & -0.4004 & 1 & \\
NTI & 0.0169 & 0 & 0.9598 & 0 & & \\
& 196 & 196 & 196 & 155 & 196 & \\
& -0.1837 & 0.7417 & 0.0038 & -0.41 & 0.8485 & 1 \\
& 0.01 & 0 & 0.9576 & 0 & 0 & \\
& 196 & 196 & 196 & 155 & 196 & 196 \\
\hline
\end{tabular}

Appendix 2. Results of initial estimation models

\begin{tabular}{|c|c|c|c|c|}
\hline & $\begin{array}{l}\text { (Pool OLS) } \\
\Delta \ln \left(y_{i, t}\right)\end{array}$ & $\begin{array}{l}\text { (RE) } \\
\Delta \ln \left(y_{i, t}\right)\end{array}$ & $\begin{array}{l}\text { (FE) } \\
\Delta \ln \left(y_{i, t}\right)\end{array}$ & $\begin{array}{l}\text { (GMM) } \\
\Delta \ln \left(\mathrm{y}_{\mathrm{i}, \mathrm{t}}\right)\end{array}$ \\
\hline $\ln \left(y_{i, t-1}\right)$ & -0.0045 & -0.0045 & $-0.197 * * *$ & $-0.415 * *$ \\
\hline Std error & $(0.007)$ & $(0.007)$ & $(0.044)$ & 0.196 \\
\hline Prob. & 0.547 & 0.548 & 0.000 & 0.036 \\
\hline$\Delta \ln (K / L)_{i, t}$ & $0.311^{* * *}$ & $0.301^{* * *}$ & $0.225^{* * *}$ & $0.194^{*}$ \\
\hline Std error & $(0.028)$ & $(0.027)$ & $(0.032)$ & 0.117 \\
\hline Prob. & 0.000 & 0.000 & 0.000 & 0.101 \\
\hline TEA & -0.0011 & -0.0012 & -0.001 & 0.002 \\
\hline Std error & $(0.001)$ & (0.001) & (0.002) & 0.004 \\
\hline Prob. & 0.612 & 0.306 & 0.607 & 0.654 \\
\hline TI & -0.0004 & -0.0002 & $-0.002 * * *$ & -0.005 \\
\hline Std error & $(0.001)$ & $(0.001)$ & $(0.000)$ & 0.004 \\
\hline Prob. & 0.919 & 0.656 & 0.004 & 0.309 \\
\hline NTI & -0.004 & -0.0004 & $0.0001^{*}$ & $0.006^{*}$ \\
\hline Std error & $(0.001)$ & (0.001) & $(0.0001)$ & 0.003 \\
\hline Prob. & 0.354 & 0.404 & 0.100 & 0.007 \\
\hline _cons & $0.053^{*}$ & $0.063^{* *}$ & $0.789 * * *$ & - \\
\hline Std error & $(0.026)$ & $(0.027)$ & $(0.164)$ & - \\
\hline Prob. & 0.403 & 0.019 & 0.000 & \\
\hline $\mathrm{N}$ & 154 & 154 & 154 & 154 \\
\hline$R-s q$ & 0.435 & 0.458 & 0.612 & J-statistic 10.61 \\
\hline
\end{tabular}

Note: standard errors in parentheses; * $\mathrm{p}<0.10,{ }^{* *} \mathrm{p}<0.05,{ }^{* * *} \mathrm{p}<.01$ 
Appendix 3. Results of Regressions per types of TEA Motivation

\begin{tabular}{llll}
\hline & $\begin{array}{l}\text { (Overall TEA) } \\
\ln \left(\mathrm{y}_{\mathrm{i}, \mathrm{t}-1}\right)\end{array}$ & $\begin{array}{c}\text { (Opportunity TEA) } \\
\ln \left(\mathrm{y}_{\mathrm{i}, \mathrm{t}-1}\right)\end{array}$ & $\begin{array}{l}\text { (Necessity TEA) } \\
\ln \left(\mathrm{y}_{\mathrm{i}, \mathrm{t}-1}\right)\end{array}$ \\
\hline $\ln \left(\mathrm{y}_{\mathrm{i}, \mathrm{t}-1}\right.$ & $-18.04^{* * *}$ & $-22.23^{* * *}$ & $-21.30^{* * *}$ \\
& $(4.650)$ & $(4.611)$ & $(4.850)$ \\
$\Delta \ln (\mathrm{K} / \mathrm{L})_{\mathrm{i}, \mathrm{t}}$ & $0.250^{* * *}$ & $0.211^{* * *}$ & $0.228^{* * *}$ \\
& $(0.0322)$ & $(0.0371)$ & $(0.0349)$ \\
TEA & -0.274 & & \\
& $(0.230)$ & & -0.0228 \\
TI & $-0.294^{* * *}$ & 0.0105 & $(0.105)$ \\
& $(0.104)$ & $(0.105)$ & $-0.194^{* *}$ \\
$\mathrm{NTI}$ & 0.0801 & $-0.173^{*}$ & $(0.0963)$ \\
& $(0.0939)$ & $(0.0970)$ & \\
OpportunityTEA & & 0.0332 & -0.0398 \\
& & $(0.0254)$ & $(0.0696)$ \\
NeccesityTEA & & & $91.95^{* * *}$ \\
cons & & $90.83^{* * *}$ & $(19.44)$ \\
\hline $\mathrm{N}$ & $78.96^{* * *}$ & $(16.97)$ & 93 \\
R-sq & $(17.40)$ & 93 & 0.540 \\
\hline
\end{tabular}

Note: standard errors in parentheses; ${ }^{*} p<0.10, * * p<0.05, * * * p<.01$

\begin{abstract}
Abstrakt
W literaturze specjalistycznej uznano, że przedsiębiorczość odgrywa istotnq rolę w napędzaniu innowacji, wzrostu gospodarczego i dobrobytu, a także wpływa na tworzenie miejsc pracy. Badacze wyrażali różne poglqdy na temat zwiq̨zku między rozwojem gospodarczym a przedsiębiorczościq w czasie. Uważa się również, że innowacje sq siłq napędowq rozwoju gospodarczego narodów. Dlatego też innowacyjna przedsiębiorczość zaczęła być uważana za kluczowy czynnik nowoczesnego rozwoju gospodarczego. Na przykład MŚP i innowacje leżq u podstaw strategii rozwoju Unii Europejskiej - strategii „Europa 2020”. Celem artykułu jest analiza roli innowacyjnej przedsiębiorczości w rozwoju gospodarczym państw członkowskich UE. Biorq̨ pod uwagę, że oba procesy: rozwój gospodarczy i innowacyjna przedsiębiorczość sq wielopłaszczyznowe, artykuł przedstawia zwiqzek między tymi dwoma fenomenami a ich specyfikq w krajach członkowskich UE. Biorqc pod uwagę charakter współczesnego przeglqdu literatury i określony cel badawczy, w niniejszym artykule przetestowano model, który obejmuje nowe lub młode i innowacyjne firmy, jako aspekty innowacyjnej przedsiębiorczości i determinanty tempa wzrostu gospodarczego. Zastosowana metoda badawcza to analiza modelu regresyjnego. Do analizy i przetwarzania danych statystycznych wykorzystano narzędzia programów Stata i SPSS. Najważniejsze wnioski z tej pracy pokazujq, że innowacyjni przedsiębiorcy (mierzeni poziomem innowacji we wczesnej fazie przedsiębiorczości (TEA)) sq bardziej obecni w krajach o wyższym poziomie rozwoju i wyższych dochodach, motywowani przez możliwości poprawy, które widzq w byciu przedsiębiorcami. Jednak wyższy stopień przedsiębiorczości, zwłaszcza tworzenie nowych firm, nie
\end{abstract}


przyczynia się znaczq̨co do przyspieszonego rozwoju gospodarczego. Wyjaśnia to zmienność motywacji (konieczność lub zorientowanie na poprawę) przedsiębiorców w krajach UE. W krajach rozwiniętych, przedsiębiorcy najprawdopodobniej sq typem Schumpetera, podczas gdy w krajach rozwijajqcych się większość z nich to właściciele sklepów. W zwiqzku z tym uważa się, że państwa członkowskie UE potrzebujq bardziej przyjaznej i skutecznej polityki tworzenia nowych firm, a także narzędzi wspierajqcych MŚP. Artykuł ma istotne praktyczne implikacje dla władz i decydentów w zakresie możliwych kierunków rozwoju innowacyjnej polityki przedsiębiorczości. Słowa kluczowe: innowacja, przedsiębiorczość, tworzenie nowych firm, Unia Europejska, wzrost gospodarczy.

\section{Biographical note}

Rodica Crudu, Ph.D., is an Associate Professor at the Academy of Economic Studies of Moldova (ASEM), Republic of Moldova and Dean of the Faculty of International Economic Relations. She also is the head of the "Education, Training and Consulting" unit of the Centre for European Studies, ASEM. She is a Fulbright Program Alumni, performing a Fulbright visiting researcher fellowship at American University in the period August 2017-January 2018. Her research is focused on international trade, the role of innovation and innovative entrepreneurship in economic development and growth, issues related to European economic integration and fostering the knowledge triangle (education-research-innovation). She is a Jean Monnet professor, being coordinator of the Jean Monnet Chair in EU Policies towards Innovation, Creativity and Entrepreneurship/ EU2INNO, ref. nr. 2016/2332-574680-EPP-1-2016-1MD-EPPJMO-CHAIR, within the Erasmus+ Programme of the European Union. 